Foreign bank entry, institutional development and credit access: firm-level evidence from 22 transition countries Maria Clara Rueda Maurer

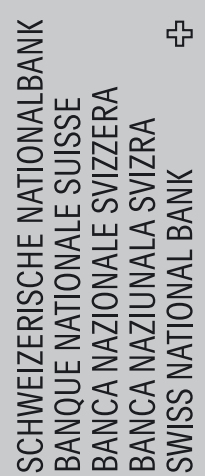


The views expressed in this paper are those of the author(s) and do not necessarily represent those of the Swiss National Bank. Working Papers describe research in progress. Their aim is to elicit comments and to further debate.

ISSN 1660-7716 (printed version)

ISSN 1660-7724 (online version)

๑ 2008 by Swiss National Bank, Börsenstrasse 15, P.0. Box, CH-8022 Zurich 


\title{
Foreign bank entry, institutional development and credit access: firm- level evidence from 22 transition countries
}

\author{
Maria Clara Rueda Maurer* \\ This version January 2008 \\ First version: October 2005
}

\begin{abstract}
In this paper I examine how the protection of creditors' rights influence the way in which foreign bank entry affects the access to credit of firms. Using a sample of more than 6000 firms in 22 transition countries I find that as bankruptcy proceedings become more inefficient foreign bank entry is more likely to crowd-out small and opaque firms. Conversely, as the protection of creditors' rights improve, the positive association between foreign banks and firms' credit constraints diminishes. These results are robust to controls for endogeneity of foreign banks. The interaction of foreign banks and the protection of creditors rights would explain the disparity of results obtained by previous studies: In countries with an adequate protection of creditor rights foreign bank entry may benefit all firms; By contrast, in countries with weak protection of creditor rights foreign bank entry is likely to result in a credit crunch.
\end{abstract}

JEL: G10, G21, G31, D82

Keywords: Institutional development, Transition, Foreign Bank Entry, Information asymmetries, Small Business Lending.

* Swiss National Bank, maria.maurer@snb.ch

I would like to thank Martin Brown, Andreas Fischer, Ralph de Haas, Steven Ongena and an anonymous referee for helpful comments.

The views in this paper are those of the author and do not necessarily represent those of the Swiss National Bank 


\section{Introduction}

In the late 1990s many developing countries opened up their financial sectors to foreign bank entry. Advocates of liberalisation prognosticated more stable and deeper financial systems thanks to technological transfers, access to better know-how and increased competition. Detractors, pointed at the possibility of cream skimming by foreign banks and, as a consequence, at a possible credit rationing of small and medium enterprises (SMEs). The financial stability enjoyed by most countries in the last decade has largely given right to financial liberalisation advocates. The jury is still out, however, with respect to the impact of foreign banks on credit access. More than ten years since the first reformers opened up their markets we have now enough data to address this issue.

The possibility that foreign bank entry may lead to credit rationing stems from information asymmetries and adverse selection costs. If information is complete, foreign bank entry should result in more and cheaper loans as inefficient credit providers are replaced by more efficient banks. But if information is costly foreign banks may only be able to serve a segment of firms. With market segmentation the net impact of foreign bank entry on total credit growth and on credit allocation becomes difficult to predict.

Yet, surprisingly enough, very little is known about the impact of foreign banks in countries with poor economic institutions, where information asymmetries can be expected to be acute. As growing numbers of developing countries with relatively weak economic institutions turn to foreign banks to strengthen their financial sectors, understanding the linkages between institutional development and financial intermediation is of more than mere theoretical interest.

This paper contributes to this debate by relating economic institutions to the net impact of foreign banks on credit access, using firm-level information in 22 transition 
economies. In particular, I test whether the interaction between the protection of creditor's rights and the share of foreign banks in the domestic financial sector has a significant effect on the access to and the costs of credit of SMEs. To my knowledge this is the first time that this relation is empirically addressed at the firm level.

I find that in transition countries foreign bank entry has resulted in more, rather than in fewer, credit constraints for the average firm. Rather than benefiting the majority of firms, as has apparently been the case in middle income countries, in transition economies only the most transparent firms, i.e. firms that use international accounting standards, benefit from foreign bank entry.

The negative impact of foreign banks on the vast majority of firms in this sample is associated to weaknesses in the bankruptcy systems of transition countries. As bankruptcy proceedings become lengthier and more expensive, the negative incidence of foreign banks on credit conditions increases. These results are robust to controls for the possible endogeneity of foreign banks.

For developing countries these findings hold an important warning. In these countries many of the expected benefits of foreign bank entry may not materialise before legal reform achieves a certain threshold.

The rest of this paper is organised as follows. Part two motivates the study and reviews the literature on foreign banks and credit access of small firms. Part three presents the empirical set up and results. Part four concludes.

\section{Motivation and literature review}

At the theoretical level, a vast body of literature explores the effect of foreign bank entry on total credit growth and credit allocation in the presence of information asymmetries (see Clarke, G. et. al. 2001b for a comprehensive literature review). The main insight of this literature may be summarised as follows: If markets are complete, financial liberalisation, by allowing the operation of more efficient banks in the home 
market, should result in deeper financial sectors and better credit allocation. In the presence of information asymmetries, however, this result may no longer hold. If foreign banks only have a comparative advantage in serving some borrowers, their entry may lead to market segmentation with ambiguous effects on total credit growth and credit allocation.

The literature on information and credit allocation typically distinguishes between two types of information (e.g Berger and Udell, 2002 and 2005, Degryse and Ongena, 2005): Hard information, such as balance sheets that comply with some minimum accounting standards, and soft information which refers to information more difficult to encode, such as the trustworthiness of potential borrowers. Hard information can be presented in standardised ways and therefore travels easily across the different organisational layers within a bank, irrespective of the distance between the person who gathers this information (the loan officer) and the person that approves the transaction (management). The transmission of soft information, by contrasts, requires a more involved interaction between loan officers and management and suffers, therefore, when the distance between these two instances in the decision-making process increases.

In markets where soft information is needed to sort out clients, small banks enjoy a natural advantage over larger and more hierarchical institutions. In the case of foreign banks, which also tend to be large and hierarchical firms, and where management and loan officers are physically located in different countries, cultural differences make the flow of soft information even more difficult. Thus foreign banks can be expected to concentrate on those segments of the market where hard information is readily available, such as large corporations or the government, and to leave small/opaque firms to local lenders. Empirical evidence has shown that, relative to domestic banks, foreign bank portfolios do indeed attach more weight to wholesale banking and give more credit to large borrowers, leaving local banks to retail banking and to look after lending to small firms (see Focarelli and Pozzolo, 2000). 
To policy makers this peculiarity of the banking industry poses an important question. If it is possible that foreign bank entry has a different impact on firms of different types, is it likely to be detrimental to the smaller and less transparent firms? Theoretically, a foreign bank bias towards hard information firms does not necessarily imply that opaque firms will definitely encounter higher credit constraints after liberalisation, as compared with their previous situation. Under certain conditions, domestic banks may profitably specialise in serving the more opaque group of firms, so that, after liberalisation, this sector may - at least - not be worse off than before. Allowing for technical spillovers and an increase in competition among domestic banks for these borrowers, access to credit may even improve.

Under which circumstances can good but opaque firms be expected to gain or lose from foreign bank entry? In a recent contribution to this debate, Detragiache E., P. Gupta and Th. Tressel(2006) offer a model that shows that, when adverse selection costs and the costs of monitoring soft information firms are sufficiently large relative to the return from projects, foreign bank entry can lead to less total lending, as opaque firms are completely left out of the financial circuit.

In this set up, two banks, a foreign and a domestic bank with two different monitoring technologies, compete for borrowers. The costs of monitoring hard information are lower for the foreign bank, whereas the domestic bank has a competitive advantage in monitoring soft information firms. The comparative advantage of the foreign bank in monitoring hard information allows it to offer lower interest rates to firms that can provide this type of information which, therefore, sort themselves out. Once the foreign bank has won all good hard information projects the domestic bank is left with a new pool that encompasses all soft information projects plus all bad projects rejected by the foreign bank.

If before foreign bank entry the domestic bank was pooling all projects and lending at a rate $r_{p}$, foreign bank entry will alter lending rates to opaque firms in one of three possible ways: 
1) If the costs of monitoring soft information are high relative to the costs of adverse selection (the costs to good opaque projects of being pooled with bad projects) the domestic bank will pool together bad projects and good but opaque projects and continue financing albeit at a rate $r_{p} *>r_{p}$.

2) If the costs of monitoring soft information are lower than the costs of adverse selection the domestic bank will separate good opaque projects and finance them at a rate $r_{s}=1+C_{s}$ such that $r_{p} *>r_{s}>r_{p}$ where $C_{s}$ is the domestic bank's cost of monitoring soft information. Bad projects will not be financed.

3) If the costs of monitoring soft information and the costs of adverse selection are very high the domestic bank will stop all lending and credit rationing will ensue.

If the domestic bank was separating hard and soft information projects before foreign bank entry will only affect hard information firms which will face lower rates.

Thus in this set up only hard information firms can benefit from foreign bank entry whereas soft information firms can never be better off: For soft information firms the impact of foreign banks can only run from irrelevant, if a separated equilibrium existed before foreign bank entry, to credit rationing if adverse selection and monitoring costs are very high ${ }^{1}$.

In this model differences in monitoring techniques are responsible for different allocation impacts. Foreign banks from industrial nations that go into other industrial countries do not generate credit rationing because there is a small distance between the monitoring techniques of banks from countries with similar levels of economic development. The wedge appears when banks from industrial countries enter

\footnotetext{
${ }^{1}$ Anther possible and related way for foreign banks to affect the access to credit pf opaque firms is through the destruction of relationship lending. In the case of transition economies I expect this channel to be of minor importance, since few relationships could have been destroyed by the time foreign banks were allowed to enter. See on this Giannetti and Ongena (forthcoming).
} 
developing markets and compete for borrowers with very different domestic banks. By extension, it may also be said that the net impact of foreign bank entry on credit access depends on the economic institutions that determine moral hazard and adverse selection costs and the costs of screening and monitoring borrowers in host countries. Hence in countries with loose accounting standards, poor firm governance, or where creditor rights are weakly enforced foreign bank entry would be more likely to result in the credit rationing of smaller firms.

Available empirical evidence on the impact of foreign banks on credit allocation offers mixed results. Testing their model predictions on macro data in a sample of low and lower middle income countries, Detragiache et.al. (2006) find that poor countries with a higher penetration of foreign banks do indeed have shallower banking sectors and experience lower credit growth. However, since they work with macro-data the impact of foreign banks on credit allocation can only be inferred from total credit growth. Examples of case studies that do observe credit allocation effects are Haber and Musachio (1994) on Mexico, and Gormley (2005) on India, who provide evidence of a worsening in credit conditions for opaque firms following foreign bank entry. Although these authors cannot link their results with country level factors, Haber and Musachio do suspect that problems related to the effectiveness of bankruptcy laws in Mexico may be at the origin of credit rationing.

However, positive effects of foreign bank entry on credit allocation in developing countries have also been reported. Two cross country studies on middle income countries (Clarke, G. et. al. 2001a, and Giannetti and Ongena, forthcoming) find that in these countries foreign bank entry enhances credit access for all firms, even if smaller firms benefit less than larger ones. In the same vein Bonin and Abel (2000) find, in a case study of Hungary, that in this country foreign bank entry did increase retail lending, both directly and indirectly, by forcing the major local bank to improve its retail banking services. 
More nuanced results are found by de Haas (2005) who shows increasing levels of leverage for small firms between 1996 and 2001 in countries such as Estonia, Hungary or Latvia, but the opposite in the case of Poland, Bulgaria, and in the Czech and Slovak Republics where leverage fell following liberalisation. Finally Bonin (2004) finds that foreign bank entry is neither a necessary nor sufficient condition for effective financial intermediation in Southeast Europe.

How to reconcile these contradictory results? My conjecture, based on the above discussion, is that differences in the protection of creditor's rights in host countries are associated to different effects of foreign bank entry on credit allocation. The protection of creditor rights is one of the economic institutions with the highest bearing on adverse selection costs. When creditor rights are poorly protected, entrepreneurs that do not exert effort can expect to go unpunished and moral hazard and adverse selection costs rise. As moral hazard and adverse selection costs rise so does the likelihood that foreign bank entry leads to credit rationing of opaque firms. Conversely, in countries with better protection of creditor rights and, consequently, lower adverse selection costs, small and opaque firms are more likely to be served by domestic banks with little or no negative impact of foreign bank entry. The forces driving these results are twofold: First, the foreign bank bias against small/opaque firms will be greater in countries where risky lending is particularly costly. Second, in these countries the moral hazard attached to the pool of projects not served by foreign banks will also be larger. In these conditions domestic banks willing to serve opaque clients will only be able to do it at significantly higher interest rates, if at all.

This paper tests this hypothesis relating institutions to the net impact of foreign banks on credit access using information on institutional development and credit access of firms in transition economies. To my knowledge, this is the first time that this relation is empirically tested.

Based on this discussion I set to answer these two related questions: 
1. Are small/opaque firms in transition countries more credit constrained as foreign bank ownership increases?

2. Does the net impact of foreign bank ownership on access to credit depend on host countries' institutional development?

\section{Empirical setup}

\subsection{Sample}

The source for the firm-level data is the EBRD-World Bank Business Environment and Enterprise Performance Survey (BEEPS) 2005. BEEPS was designed to analyse the quality of governance and the investment climate from a firm-level perspective for the countries of Eastern Europe and the former Soviet Union. For the purpose of the present study, BEEPS presents three characteristics that makes it particularly attractive. First, BEEPS ensures representation of firms of all sizes in all countries; Second, while other data bases rely on information provided by firms that submit financial data to local authorities (i.e. hard information firms), firms in the BEEPS sample were randomly selected from business directories and yellow pages. These two features ensure the inclusion in the sample of small and opaque firms; Third, BEEPS includes both firms with and without credit, allowing the direct observation of the extent of credit supply constraints.

This last feature of the data makes this paper especial among other studies of credit in transition countries (e.g Gianetti and Ongeny, forthcoming, Bonin 2001 and 2004, or de Haas 2005) in that the focus here are the losers rather than winners of economic reform. Studies based on samples of firms with credit can tell whether different institutions, e.g., different legislation on foreign bank entry, generate -or not- better credit conditions for these firms. What they cannot see, but the present study can, is whether some firms are left out in the cold as a result of the reform. 
However it should be noted that, since the data is purely cross-sectional, I cannot estimate the impact of foreign banks on credit access over time. Credit rationing can arise if foreign banks have difficulties screening borrowers, and local banks cannot profitably serve those good projects 'wrongly' rejected by the foreign bank. In that sense, foreign bank entry may lead to more credit constraints for opaque firms at an initial date but this bias may become less important over time, as foreign banks acquire the knowledge they require to process soft information and/or firms upgrade their signals. Lacking this time dimension, the terms foreign bank entry, foreign bank ownership and foreign bank presence are used interchangeably.

The sample covers 6.189 firms in the following 22 countries: Albania, Armenia, Azerbaijan, Belarus, Bulgaria, Croatia, the Czech Republic, Estonia, Georgia, Hungary, Kazakhstan, Kyrgyzstan, Latvia, Lithuania, Macedonia, Moldova, Poland, Romania, Slovakia, Slovenia, Tajikistan and Ukraine.

\subsection{Dependent variables}

BEEPS includes two questions about the impact of credit constraints of firms. The first is whether access to commercial credit constitutes an obstacle to growth. The second is whether the costs of commercial finance constitute an obstacle to growth. Answers to these questions are ordered in an scale of 1 to 4 with 4 signifying that the respective constraint is a major obstacle to growth. Based on these indicators I construct two dummy dependent variables, access to and cost of credit. These two variables take value of one when the corresponding constraint is found to be a major obstacle to growth, and zero otherwise.

In table 1 both indicators of credit constraints are related to two proxies of firm opacity and to bank ownership. The indicators of firm opacity are size, a traditional proxy of opacity, and a narrower indicator of opacity which distinguishes between firms with and without international accounting standards. Small firms, expected to rely more on soft information than larger firms, are defined, as usual, as firms of less than 50 
employees. With the narrower indicator only firms that use international accounting standards, irrespective of their size, are considered transparent, i.e. only firms with international accounting standards are expected to pass hard information to banks. Regarding bank ownership the table distinguishes between countries where foreign banks dominate (i.e. countries where foreign banks own more than $50 \%$ of total banking assets) and the rest.

$27 \%$ of small firms versus $20 \%$ of large firms find that the costs of credit are a major obstacle to growth. This is as expected since small firms are generally found to have more problems acceding credit than large firms. When the proxy for opacity is the narrower definition of 'use of international accounting standards' the difference is even more striking: $26 \%$ of opaque firms versus $17 \%$ of transparent firms find that the cost of credit is a major obstacle to growth.

Results are more interesting however when the sample is split between countries where foreign banks dominate and the rest. In the first sub sample $30 \%$ of all opaque firms versus only $16 \%$ of transparent firms find that the costs of credit are a major obstacle to growth. Parson chi 2 tests show that these difference are significant at the $1 \%$ level of confidence. Similar (albeit not significant) differences are observed between small and large firms: relatively more small firms find that the costs of credit are a major obstacle to growth in countries where foreign banks dominate while the opposite is true for larger firms. Interestingly in terms of access to credit foreign banks seem to punish opaque firms without affecting transparent firms: $12 \%$ of transparent firms (15\% of large firms) find that access to credit is a major obstacle to growth irrespective of whether these firms are located in countries where foreign banks dominate or not. By contrast significantly less opaque firms located in countries where domestic banks dominate meet major problems acceding credit (16\%) than similar firms operating in countries where foreign banks dominate $(24 \%)$.

These figures suggest that in these countries cream skimming by foreign banks may be resulting indeed in the type of credit crunches expected by adverse selection models 
such the Detriagace et.al. model reviewed above. That is, as foreign bank presence increases the likelihood that opaque firms meet greater credit constraints seems to rise. The next section explores this possibility econometrically.

\subsection{Estimation of the impact of foreign banks on credit constraints}

The point of departure is the estimation of the impact of foreign banks on the probability that firms' growth prospects are compromised by credit constraints. Given the dichotomous character of the dependent variables, the method of estimation is the probit model. The equation estimated is:

1. $\operatorname{Pr}($ Credit constraint $i, j=1)=\varphi(\beta o+\beta 1$ Small firm $+\beta 2$ Transparent firm + $\beta 3$ Foreign bank share $_{j}+\beta 3$ Fij $+\beta 4 \mathrm{C}_{j}$ )

where $\varphi$ is the standard normal cumulative distribution

This equation states that the probability of firm $i$ in country $j$ being credit constrained depends on firm size, firm transparency, the share of foreign owned banks in the banking sector of country $j$, and two vectors (Fij and $\mathrm{Cj}$ ) of other firm and country characteristics that may affect access to credit (All variables and their sources are described in table 2. Basic data is shown on table 3). Adding to 1) the interaction of foreign banks and firm size (transparency) brings into the analysis the marginal impact of foreign banks on credit access of small and opaque firms.

If foreign banks are exogenous in 1) $\beta 3$ would measure the impact of foreign banks on the credit constraints meet by the average firm the sample. The interaction term foreign banks and firm opacity, in turn, would measure the extent to which foreign bank presence closes or widens the credit gap between small (opaque) and larger (transparent) firms. 


\subsubsection{Dealing with endogeneity of foreign banks}

Foreign banks, however, need not be exogenous in models of credit allocation. Empirical studies have shown that in developing countries foreign bank entry indeed is closely correlated to the size of the financial sectors and the expected economic growth of host countries. According to Focarelli and Pozzolo (2001) for example, foreign banks are more likely to be located in countries with shallow financial sectors and inefficient domestic banks where expected returns are high. Hence credit constraints may be a determinant of foreign bank presence rather than its consequence. In this case reverse causation would cause the probit estimations of 1) above to be biased.

Endogeneity concerns are addressed in two different ways. First equations 1) is estimated with 3 years lagged values of foreign bank penetration; Second as robustness tests instrumental variables are used to identify causality.

To instruments for foreign bank entry I use distance from Düsseldorf, in log form, and per capita income in 1989, also in log form. This choice of instruments is based on the assumption that foreign banks entered first those countries that were the most promising in terms of expected growth at the start of transition, and those that were closest, culturally and physically speaking, to the West. The above mentioned study of Focarelly and Pozzolo (2000) offers strong support to this hypothesis showing that profitability and the cultural and physical distance between home and host countries are important determinants of foreign bank location in developing countries. The OLS regression of foreign banks on these two indicators confirms the strength of the instruments. On their own distance from Düsseldorf and the log of per capita GDP in 1989 explain 39\% of foreign bank presence in 2004. Both indicators are significant, at $1 \%$ and $5 \%$ levels of confidence, respectively.

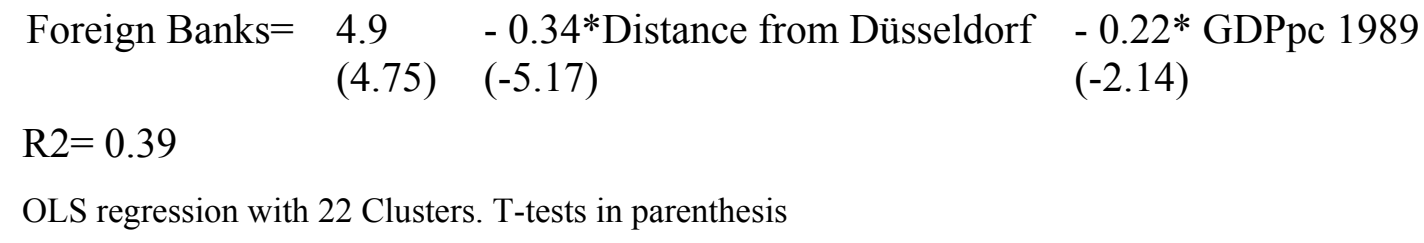


Further, to be valid instruments the indicators of distance and initial levels of economic development must closely reflect expected growth at the start of transition but should not have any direct impact on current credit conditions. Various empirical papers lend support to this hypothesis. As Fischer (2004) and the literature reviewed therein show, the effect of initial conditions - main components of which are distance from the West and income at the start of transition- on economic growth, while strong at the beginning, wears off over time. Estimations of the impact of initial conditions on GDP growth typically show a lack of significance following the tenth year after transition (e.g de Melo et. al.1997).

\subsubsection{Results}

Tables 4 a) and b) present results of the basic estimations for the two indicators of credit constraints, access and costs. Columns 1 and 3 show results for two different probit estimations: in column 1 the share of foreign banks in 2004 is entered as explanatory variable. In column 2 the lagged value of this share, i.e. the share of foreign banks in 2001, is used in order to minimize endogeneity concerns. In column 3 results with instrumental variables are presented.

Of the firm control variables, the most important determinants of credit constraints are size, transparency and origin of ownership: Small firms are significantly more likely to find that both access to and the costs of credit are major obstacles to growth, whereas transparent firms and foreign-owned firms are significantly less likely to meet major credit constraints than opaque and domestic-owned firms. Opacity, in other words, or the risk attached to small domestic-owned business that cannot transmit hard information, seems to be the main determinant of credit constraints in this sample, with other variables like profitability or even relations with foreign partners playing no visible role in credit facilitation. 
The importance of opacity in the determination of credit constraints is also consistent with the negative and significant coefficient obtained for the number of banks operating in the country. In line with the expectation of models of credit with asymmetric information, as the number of banks increases firms are more likely to meet major credit constraints suggesting that the expectation of long relations between banks and borrowers are important facilitators of credit in these countries.

Regarding other country controls, results show that government-owned banks do not alleviate credit access conditions for these firms and that, on the contrary, a higher participation of state-owned banks is associated with more credit constraints, at least when the constraint is measured as access to credit. Finally, inflation and government debt also negatively affect credit access as previous studies of credit in transition countries have shown.

Turning now to foreign bank entry, the variable of interest here, the table shows that as the share of foreign-owned banks increases so does the probability of a firm stating that access to and the cost of credit are major obstacles to growth. The negative impact of foreign banks on credit constraints is very large. The estimated probability of a firm declaring that the costs of credit are a major obstacle to growth jumps from $19 \%$, when the share of foreign banks is $5 \%$, that is in a country like Tajikistan, to $26 \%$ when the share is $75 \%$, as was the case for Bulgaria in 2001.

These results are not explained by endogeneity bias. The first step results of the IV probit estimations of column 3 (not shown) have an R2 of 0.70 , confirming the strength of the instruments chosen. The Amemiya-Lee-Newey test of overidentifying restrictions does not allow me to reject the null hypothesis of exogeneity of the instruments. The Wald test of exogeneity for both IVprobit estimations (costs and access) support the use of the instrumental variables as does a Hausman test comparing the probit and the IVprobit results ${ }^{2}$. Endogeneity, however, is not responsible for the

\footnotetext{
${ }^{2}$ Tests statistics are not shown but available at request
} 
positive relation between foreign banks and credit constraints. If anything, the endogeneity bias lowers the coefficient, masking some of the impact of foreign banks on credit constraints. The consistent estimated coefficients of foreign banks are larger, positive, and significant in both equations.

Confident that endogenity bias is not responsible for the positive association between foreign banks and credit constraints, and given that probit models are easier to manipulate than the instrumental variables models, in what follows I present results of probit estimations using, in order to minimize endogenity concerns, only lagged values of foreign bank presence. Tables 5 and 6 explore, with this methodology, the impact of foreign banks and of competition in the banking sector on credit constraints of firms of different size and levels of transparency. The tables present results for equation 1) estimated with foreign banks in 2001 and the number of banks in 2005 split between small and large (opaque and transparent) firms. Note that these interaction terms measure the main impact of foreign banks and competition on small and large (transparent and opaque) firms, not their marginal effects. For this reason there is no need to correct the probit coefficients. Linear tests for the equality of coefficients and nonlinear tests ${ }^{3}$ for the proportionality of coefficients were applied.

When firms are split across size an increase of foreign banks is found to result in higher costs of credit for small but not for large firms and to negatively affect access to credit for all firms, independently of size. The difference in the impact of foreign banks on small and large firms are significant at $1 \%$ level of confidence and there is strong evidence of no proportionality between coefficients. It can be concluded, therefore, that foreign banks affect large and small firms in different ways whereby small but not large firms are crowded out after foreign bank entry. Moreover, when firms are split along the narrower definition of transparency I find that only opaque

\footnotetext{
${ }^{3}$ The nonlinear tests applied are: $\beta($ smallfirms*foreign banks $) * \beta($ number banks $*$ Large firms $)=$ $\beta$ (large firms*foreign banks)* $\beta$ (number of banks *small firms)
} 
firms are negatively affected by foreign bank entry. Transparent firms, by contrast, experience significantly less credit constraints as foreign banks become more dominant, at least when the constraint is measured as the cost of credit. Again the appropriate tests confirm that these differences are significant at the $1 \%$ level of confidence and do not depend on the proportionality of effects. Competition in the banking sector, by contrast, is positively related to credit constraints for all firms independently of size and level of transparency.

To summarize, in transition countries foreign bank entry appears to benefit only very transparent firms, i.e. firms that use international accounting standards, while having a negative effect on the rest of firms. For the vast majority of firms in this sample foreign bank entry is associated with higher costs of and less access to credit.

These results stand in sharp contrast with Clarke et. al. 2001 who, estimating basically the same equation on a different sample of countries, find that foreign banks and lower concentration rates unequivocally improve firm's access to credit. Further, these authors find that their results hold independently of firm size, even if SMEs seem to benefit less than larger firms. In the same vein, Giannetti and Ongena (forthcoming) find, for a sample of 11 Eastern European countries, that foreign lending positively affects firm's growth, again independently of firm size.

My conjecture is that what explains the different results are the levels of institutional development which differ between this and the Clarke et. al sample, and the fact that, unlike Giannetti and Ongena I am analysing the impact of foreign bank entry on very small firms where information asymmetries can be expected to be more acute. Whereas Clarke et. al use a sample of middle-income countries, with which one may associate relatively higher levels institutional development, the BEEPS sample includes a large number of countries with very low levels of legal creditor protection, corporate governance, and law enforcement. In the case of Giannetti and Ongena, their study is focused on medium and large firms that submit financial data to local authorities and can, therefore, be expected to suffer less from any form of credit 
rationing derived from opacity. In fact, in line with their results I find that transparent firms do benefit from foreign bank entry. It is opaque firms that suffer. To explore the validity of this assumption the next section brings into the analysis the impact of institutions.

\subsection{Empirical analysis of institutions}

Having established the impact of foreign banks on access to credit the second step is to add to the analysis the influence of economic institutions. The main hurdle to overcome here is to find indicators of specific economic institutions, such as the protection of creditor rights, that are not highly correlated with other macroeconomic and financial sector controls that may also affect credit conditions. This is particularly difficult in the case of transition countries where a large number of institutional reforms were launched, and are being pursued, simultaneously. To give an idea of the magnitude of the problem table 7 shows correlations between various indicators of creditor rights, the presence of foreign banks, inflation and government debt.

Of the indicators presented in the table perhaps the most widely used proxies of creditor rights are the legal index of creditor rights of the World Bank, and, in the case of transition countries, the EBRD index of enterprise reform. The first of these two indexes measures the extent to which collateral and bankruptcy laws facilitate lending in a scale that ranks countries from 1 (worst) to best (10). The second indicator ranks countries according to the adequacy of the written laws that affect firm governance and the protection of creditor rights, as well as to the effectiveness of the implementation of these laws. Any of these two indexes would convey the information necessary to test whether the protection to creditor rights affects indeed the way in which foreign banks operate in these countries. However, as shown in the table, the correlation of these two indicators with other variables in the model, and in particular with foreign banks, precludes their use. 
Another good if narrower indicator would be the cost of closing a business of the 'Doing Business' dataset of the World Bank. This index measures the time (years to complete proceedings), costs (in percentage of estate) and recovery (cents on the dollar recouped by creditors through the bankruptcy or insolvency proceedings) of bankruptcy proceedings involving domestic entities. Although this index is, like the two previously discussed ones, highly correlated with foreign bank presence, two of its components, time and costs of proceedings, are not. Therefore I use these two indexes, alternatively, as proxies for protection of creditor rights.

Based on the vast literature on law and finance (e.g. La Porta et. al 1997 and 1998; Galindo A. and A. Micco 2005, Gianetti, 2002 ), I expect creditor's rights to have a positive and direct impact on credit access. In addition, I expect them to affect credit access through their interaction with foreign banks.

\subsubsection{Results}

Results of estimations with institutional variables are presented in tables 8 a) and b)-. In line with results by previous studies I find a direct and important impact of economic institutions on credit constraints. These results are particularly clear in the equation for costs of credit. In this case, when either the costs of bankruptcy proceedings or the time to complete the proceedings increase, so does the likelihood that firms meet major credit constraints. And the effect is not negligible: As shown in the lower panel of table 8 a) a reduction in the costs of proceedings from $42 \%$ of the estate, as is the case in Ukraine, to $13 \%$, as is the case in a country like Latvia, would reduce the probability that an Ukrainian firm meets major credit constraints in the costs of credit from $45 \%$ to $22 \%$. Similarly if the time to complete proceedings were to be reduced from 5.8 years, as is the case today in Belarus, to 2.8 as is the case in Moldova, the probability that a firm in Belarus meets major credit constraints would fall from $42 \%$ to $23 \%$. These are major gains. Or, put differently: Firms in transition countries are paying a high price for the inefficiencies in these countries' bankruptcy systems. 
The third and fourth groups of results in the tables show the same regressions with an indicator of general institutional development, the logarithm of per capita GDP, which should control for other developments, different from the efficiency of the bankruptcy legislation, that may affect firms' credit constraints. Clearly, economic development, or the concomitant institutional developments, matters. The cost of credit significantly falls as this indicator rises. But the specific indicators of protection of creditor rights remain significant even after adding this control. That is, the protection of creditor's rights, independently of other economic or institutional developments, affects the access to credit of firms. In countries where creditors rights are weakly protected, firms have less access to credit and are also more likely to find that the costs of credit constitute a major obstacle to growth.

But, does the protection of creditor's rights also influence the way in which foreign banks affect access to credit and its costs? Results presented in table 9 a) and b) show that this is indeed the case. The table presents the corrected interaction terms ${ }^{4}$ between foreign banks and the costs of bankruptcy proceedings and between foreign banks and the time to complete proceedings. In the case of the costs of credit both interaction terms are positive and significant for all observation in the sample. In other words, inefficiencies in bankruptcy proceedings not only have a direct negative impact on credit access, they also affect firms through their interaction with foreign banks. As bankruptcy proceedings become lengthier and more costly, the negative impact of foreign banks on the costs of credit becomes more pronounced. In the case of access to credit, institutional variables appear to be of lesser importance.

\footnotetext{
${ }^{4}$ The coefficients of the probit interaction terms were corrected with the Norton's 'inteff' estimation procedure for STATA.
} 


\section{Conclusions}

The main contribution of this paper is the analysis of the influence of economic institutions on the effect of foreign banks on credit access. Working on a sample of mainly small and opaque firms in 22 transition economies I find that in these countries only very transparent firms have benefited from foreign bank entry. For large numbers of small and opaque firms foreign bank entry has resulted in less and more costly commercial loans. I present strong evidence that these results can be explained by the type of economic institutions that prevail in these countries. In particular, I show that the negative impact of foreign banks on the costs of credit increases significantly with the worsening of the legal environment, characterised by lengthy and expensive bankruptcy proceedings.

These results suggest that pooling data of countries with different legal environments can be misleading. What obtains for rich and middle income countries, with presumably better legal systems, does not necessarily apply to low income countries where economic institutions are weaker.

For poor countries, the policy implications of these results are important. Strengthening the financial sector via foreign bank entry is likely to be harmful to large numbers of firms if it is not accompanied by the required upgrading of their legal systems. 


\section{References}

Barth J.R., G. Caprio and R. Levine (2001): "The Regulation and Supervision of Banks around the World: a new Database", In R.E. Litan and R. Herrig (Eds) Integrating Emerging Market Countries into the Global Financial System, Washington, DC: Brookings Institutions Press.

Beck T., A. Demirgüc-Kunt and V. Maksimovic (2004): "Bank Competition and Access to Finance: International Evidence", Journal of Money, Credit and Banking, $36(2), 627-647$.

Berger, A.N. and G. F. Udell (2002): 'Small business credit availability and relationship lending: the importance of bank organizational structure', The Economic Journal, 112, (February) F32-F53

(2006): 'A more complete conceptual framework for SME finance', Journal of Banking and Finance 30, 2945-2966.

Berglöf E. and P. Bolton (2002): "The Great Divide and Beyond: Financial Architecture in Transition", Journal of Economic Perspectives, 16(1), 77-100.

Bonin J.P. (2004): "Banking in the Balkans: The Structure of Banking Sectors in Southeast Europe", Economic Systems, 28, 141-153.

Bonin J.P. and I. Abel (2000): "Retail Banking in Hungary: A Foreign Affair?", William Davidson Institute Working Paper 356.

Clarke G., R. Cull and M. S. Martinez Peria (2001a): "Does Foreign Bank Penetration Reduce Access to Credit in Developing Countries? Evidence from Asking Borrowers", World Bank Policy Research Paper No.2716.

Clarke G., R. Cull and M. Soledad Martinez Peria and S. M. Sanchez (2001b): "Foreign Bank Entry: Experience, Implications for Developing Countries, and Agenda for further Research" World Bank Policy Research Paper No.2698.

De Haas R. (2005): "Multinational Banks ansd Credit Growth in Transition Economies", PhD Thesis, Universiteit Utrecht

De Melo Martha; Cevdet Denizer; Alan Gelb and Stoyan Tenev (1997) "Circumstances and choice: The role of initial conditions and Policies in Transition Economies", World Bank, Working Papers - Transition Economies. Current and former socialist economies. No. 1866.

Degryse, H., and S. Ongena (2005): Distance, Lending Relationships, and Competition', The Journal of finance, vol LX, No. 1 February 
, 2006. "The Impact of Competition on Bank Orientation and Specialization," Tilburg University, Mimeo.

Detragiache E., P. Gupta and T. Tressel (2006): "Foreign Banks in Poor Countries: Theory and Evidence", IMF Working Paper WP/06/18.

EBRD (2002): “Transition Report 2002”.

Elsas, R., 2005, "Empirical Determinants of Relationship Lending," Journal of Financial Intermediation 14, 32-57,

Fischer, S and R. Sahay (2004), Transition economies: The role of institutions and initial conditions', IMF, Festschrift in honor of Gillermo Calvo, April 15-16

Focarelli, D. \& A. F. Pozzolo, 2000. "The determinants of cross-border bank shareholdings: an analysis with bank-level data from OECD countries," Proceedings, Federal Reserve Bank of Chicago, issue May, pages 199-232.

Fries S. and A. Taci (2002): "Banking Reform and Development in Transition Economies", EBRD Working Paper 71.

Fries S., T. Lysenko and S. Polanec (2003): "The 2002 Business Environment and Enterprise Survey: Results from a Survey of 6'100 Firms", EBRD Working Paper 84.

Galindo, A. and A. Micco (2005) Bank Credit to Small and Medium Enterprises: The Role of Credito Protection', Research Department, Inter-American Development Bank.

Giannetti M. and S. Ongena (forthcoming): "Financial Integration and firm performance: Evidence from Foreign Bank Entry in Emerging Markets, Review of finance

Giannetti, M. 2000. "Do Better Institutions Mitigate Agency Problems? Evidence from Corporate Finance Choices," Temi di discussione Economic working papers 376, Bank of Italy, Economic Research Department.

Gormley T.A. (2005): "Banking Competition in Developing Countries: Does Foreign Bank Entry Improve Credit Access?", Working Paper, MIT.

Haber S. and Musacchio A. (2004) "Foreign Banks and the Mexican Economy, 19972004", Stanford University SCID Working Paper 228.

(1998) Law and Finance. Journal of Political Economy 106 (6): 1113-1155

Petersen M.A. and R. G. Rajan (1995): "The Effect of Credit Market Competition on Lending Relationships", Quarterly Journal of Economics 110, 407-443.

World Bank (2002) Transition, the First Ten Years, Analysis and Lessons for Eastern Europe and the Former Soviet Union' 
Table 1: Distribution of firms with credit constraints by size and transparency

\begin{tabular}{|c|c|c|c|c|c|c|c|}
\hline & \multirow[b]{3}{*}{$\begin{array}{c}\text { Total } \\
\text { number of } \\
\text { firms }\end{array}$} & \multicolumn{6}{|c|}{ Credit constraint } \\
\hline & & \multicolumn{3}{|c|}{$\begin{array}{c}\text { Cost } \\
\% \text { of firms with credit constraints }\end{array}$} & \multicolumn{3}{|c|}{$\begin{array}{c}\text { Access } \\
\% \text { of firms with credit constraints }\end{array}$} \\
\hline & & $\begin{array}{l}\text { Whole } \\
\text { sample }\end{array}$ & $\begin{array}{c}\text { Where } \\
\text { For. } \\
\text { banks } \\
\text { dominate } \\
\end{array}$ & $\begin{array}{l}\text { In rest of } \\
\text { countries }\end{array}$ & $\begin{array}{l}\text { Whole } \\
\text { sample }\end{array}$ & $\begin{array}{c}\text { Where } \\
\text { For. } \\
\text { banks } \\
\text { dominate } \\
\end{array}$ & $\begin{array}{l}\text { In rest of } \\
\text { countries }\end{array}$ \\
\hline Opaque firms & 5140 & $26 \%$ & $30 \%$ & $22 \%$ & $20 \%$ & $24 \%$ & $16 \%$ \\
\hline Transparent firms & 1049 & $17 \%$ & $16 \%$ & $22 \%$ & $12 \%$ & $12 \%$ & $12 \%$ \\
\hline Small firms & 4494 & $27 \%$ & $30 \%$ & $22 \%$ & $20 \%$ & $23 \%$ & $16 \%$ \\
\hline Large firms & 1695 & $20 \%$ & $19 \%$ & $21 \%$ & $15 \%$ & $16 \%$ & $14 \%$ \\
\hline
\end{tabular}

Small firms are firms of less than 50 employees. Transparent firms are firms with international accounting standards. Countries where foreign banks dominate are those where foreign banks own more than $50 \%$ of bank assets. 
Table 2 Definition of variables, expected sings and sources

\begin{tabular}{lll}
\hline Variable & Definition and expected signs & Source
\end{tabular}

Main determinants of credit constraints

Firm size:

Firm transparency

Foreign bank ownership. I

Firm-level controls

Profitability

Foreign-owned firm

Exports

\section{Country-level controls}

Competition in the banking sector

Government-owned banks

Inflation

Government Debt
Dummy. Small firms (1) are firms with fewer than 50 employees. $(+)$

Dummy: Transparent firms (1) are firms with international accounting standards. $(-)$

Assets share of foreign owned banks in percent. in 2001 and in 2004. (?)

Ratio of gross profits to total sales in 1998/1999. (-)

Share of firm assets in foreign hands. These firms are expected to have more access to alternative sources of credit. (-)

Share of exports in total sales. Since commercial relationships with firms located abroad normally involve bank transactions, firms that engage in these activities are more likely to cultivate their relationships with banks and have, as a result, better access to credit. (-)

Number of banks operating in each country in 2004.. Competition should improve access if information is perfect. If relationship lending is important competition would increase credit constraints. (?)

Share of banking sector assets controlled by banks with at least $51 \%$ state ownership in 2004. (+).

Average CPI inflation 2002-2004. (+).

Percentage of GDP in 2004. (+)
IFS

BEEPS

BEEPS

For the 2004 figure EBRD. For the 2001 figure, World Bank database on bank supervision.

BEEPS

BEEPS

BEEPS

EBRD

EBRD

EBRD 
Table 3 Basic data

\begin{tabular}{|c|c|c|c|c|c|c|c|c|c|c|c|}
\hline Country & $\begin{array}{l}\text { N. of } \\
\text { firms }\end{array}$ & $\begin{array}{l}\% \\
\text { Small } \\
\text { firms } \\
\end{array}$ & $\begin{array}{l}\% \\
\text { transpa } \\
\text { rent } \\
\text { firms } \\
\end{array}$ & $\begin{array}{l}\text { Mean } \\
\text { profits }\end{array}$ & $\begin{array}{l}\text { Mean } \\
\text { foreign } \\
\text { owner- } \\
\text { ship }\end{array}$ & $\begin{array}{l}\text { Mean } \\
\text { exports }\end{array}$ & $\begin{array}{l}\text { For. } \\
\text { banks }\end{array}$ & $\begin{array}{l}\text { Gov.- } \\
\text { owned } \\
\text { banks }\end{array}$ & $\begin{array}{l}\text { N. of } \\
\text { banks }\end{array}$ & Inflation & $\begin{array}{l}\text { Gov. } \\
\text { debt }\end{array}$ \\
\hline Albania & 184 & $76 \%$ & $14 \%$ & $21 \%$ & $7 \%$ & $14 \%$ & $93 \%$ & $7 \%$ & 16 & $4 \%$ & $56 \%$ \\
\hline Armenia & 332 & $81 \%$ & $31 \%$ & $21 \%$ & $6 \%$ & $7 \%$ & $57 \%$ & $0 \%$ & 20 & $4 \%$ & $33 \%$ \\
\hline Azerbaijan & 259 & $71 \%$ & $8 \%$ & $24 \%$ & $12 \%$ & $4 \%$ & $6 \%$ & $56 \%$ & 44 & $4 \%$ & $19 \%$ \\
\hline Belarus & 255 & $74 \%$ & $2 \%$ & $20 \%$ & $8 \%$ & $10 \%$ & $20 \%$ & $70 \%$ & 32 & $30 \%$ & $9 \%$ \\
\hline Bulgaria & 244 & $75 \%$ & $24 \%$ & $21 \%$ & $9 \%$ & $9 \%$ & $82 \%$ & $2 \%$ & 35 & $5 \%$ & $41 \%$ \\
\hline Croatia & 152 & $62 \%$ & $61 \%$ & $21 \%$ & $10 \%$ & $14 \%$ & $91 \%$ & $3 \%$ & 37 & $2 \%$ & $44 \%$ \\
\hline Czech Rep & 296 & $78 \%$ & $5 \%$ & $24 \%$ & $8 \%$ & $9 \%$ & $85 \%$ & $3 \%$ & 35 & $2 \%$ & $31 \%$ \\
\hline Estonia & 139 & $73 \%$ & $83 \%$ & $23 \%$ & $15 \%$ & $11 \%$ & $98 \%$ & $0 \%$ & 9 & $3 \%$ & $6 \%$ \\
\hline Georgia & 147 & $77 \%$ & $39 \%$ & $24 \%$ & $11 \%$ & $7 \%$ & $58 \%$ & $0 \%$ & 21 & $5 \%$ & $47 \%$ \\
\hline Hungary & 410 & $74 \%$ & $13 \%$ & $23 \%$ & $12 \%$ & $14 \%$ & $63 \%$ & $7 \%$ & 38 & $6 \%$ & $57 \%$ \\
\hline Kazakhstan & 510 & $72 \%$ & $8 \%$ & $20 \%$ & $8 \%$ & $4 \%$ & $6 \%$ & $4 \%$ & 35 & $6 \%$ & $11 \%$ \\
\hline Kyrgyzstan & 176 & $66 \%$ & $42 \%$ & $20 \%$ & $10 \%$ & $9 \%$ & $70 \%$ & $4 \%$ & 19 & $5 \%$ & $94 \%$ \\
\hline Latvia & 137 & $77 \%$ & $25 \%$ & $23 \%$ & $8 \%$ & $9 \%$ & $49 \%$ & $4 \%$ & 23 & $4 \%$ & $15 \%$ \\
\hline Lithuania & 146 & $68 \%$ & $19 \%$ & $20 \%$ & $11 \%$ & $14 \%$ & $91 \%$ & $0 \%$ & 12 & $0 \%$ & $20 \%$ \\
\hline Macedonia & 155 & $75 \%$ & $15 \%$ & $23 \%$ & $8 \%$ & $10 \%$ & $47 \%$ & $2 \%$ & 21 & $1 \%$ & $44 \%$ \\
\hline Moldova & 266 & $69 \%$ & $9 \%$ & $23 \%$ & $9 \%$ & $11 \%$ & $34 \%$ & $18 \%$ & 16 & $10 \%$ & $46 \%$ \\
\hline Poland & 865 & $75 \%$ & $7 \%$ & $23 \%$ & $5 \%$ & $8 \%$ & $71 \%$ & $19 \%$ & 57 & $2 \%$ & $42 \%$ \\
\hline Romania & 478 & $66 \%$ & $23 \%$ & $27 \%$ & $7 \%$ & $10 \%$ & $59 \%$ & $8 \%$ & 32 & $17 \%$ & $19 \%$ \\
\hline Slovak Rep & 151 & $72 \%$ & $8 \%$ & $20 \%$ & $9 \%$ & $10 \%$ & $97 \%$ & $1 \%$ & 21 & $6 \%$ & $42 \%$ \\
\hline Slovenia & 194 & $71 \%$ & $18 \%$ & $25 \%$ & $8 \%$ & $21 \%$ & $20 \%$ & $13 \%$ & 22 & $6 \%$ & $29 \%$ \\
\hline Tajikistan & 187 & $61 \%$ & $5 \%$ & $21 \%$ & $8 \%$ & $7 \%$ & $6 \%$ & $12 \%$ & 12 & $12 \%$ & $39 \%$ \\
\hline Ukraine & 506 & $74 \%$ & $11 \%$ & $23 \%$ & $8 \%$ & $6 \%$ & $12 \%$ & $8 \%$ & 160 & $5 \%$ & $26 \%$ \\
\hline
\end{tabular}


Table 4 a): Impact of foreign banks on credit constraints: Dependent variable is cost of credit

1) Probit regression. Foreign banks is the share of foreign-owned bank assets in 2004. 2) Probit regression with foreignbanks lagged 3 years. 3 ) IV probit regression. Foreign banks in 2004 are instrumented with the logarithms of distance from Düsseldorf and per capita income in 1989 plus all other exogenous variables. $*$ denotes significance at $10 \%, * *$ at $5 \%$ and $* * *$ at $1 \%$ level of confidence.

1)

Financial sector indicators

Foreign banks

State-owned banks 2004

Number of banks 2004

Firm controls

Small firm dummy

Transparent firm dummy

Profit margins 2004

Foreign -owned firm (share ownership 2004)

Exports (\% over total sales 2004)

Macro controls

Inflation (average 2002-2004)

Government debt (2004)

Constant

Number of obs =

Wald chi2(10) =

Prob $>$ chi $2=$

Pseudo R2
0.224

0.093

0.005

0.136

$-0.202$

0.000

$-0.005$

0.000

1.022

1.168

$-1.551$

6189

294.12

0442

$\begin{array}{llrllllll}(0.075) & * * * & 0.315 & (0.069) & * * * & 0.363 & (0.102) & * * * \\ (0.129) & & 0.096 & (0.129) & & 0.135 & (0.138) & \\ (0.001) & * * * & 0.006 & (0.000) & * * * & 0.006 & (0.001) & * * * \\ & & & & & & & \\ (0.043) & * * * & 0.134 & (0.044) & * * * & 0.132 & (0.044) & * * * \\ (0.054) & * * * & -0.192 & (0.054) & * * * & -0.212 & (0.054) & * * * \\ (0.001) & & 0.000 & (0.001) & & 0.000 & (0.001) & \\ (0.001) & * * * & -0.005 & (0.001) & * * * & -0.005 & (0.001) & * * * \\ (0.001) & & 0.000 & (0.001) & & 0.000 & (0.001) & \\ & & & & & & & \\ (0.361) & * * * & 1.232 & (0.365) & * * * & 1.175 & (0.381) & * * * \\ (0.111) & * * * & 1.238 & (0.107) & * * * & 1.120 & (0.119) & * * * \\ (0.089) & * * * & -1.638 & (0.091) & * * * & -1.631 & (0.098) & * * *\end{array}$

6189

288.56

$\begin{array}{rr}6189 & 6189 \\ 302.54 & 288.56 \\ 0 & 0 \\ 0.0457 & 0\end{array}$

Probability of credit constraints associated with different levels of foreign bank penetration (based on col. 2)

Foreign bank share

$5 \%$

$50 \%$

$75 \%$
Associated probability
$19 \%$
$23 \%$
$26 \%$ 
Table 4 b): Impact of foreign banks on credit constraints: Dependent variable is access to credit

1) Probit regression. Foreign banks is the share of foreign-owned bank assets in 2004. 2) Probit regression with foreignbanks lagged 3 years. 3 ) IV probit regression. Foreign banks in 2004 are instrumented with the logarithms of distance from Düsseldorf and per capita income in 1989 plus all other exogenous variables. * denotes significance at $10 \%, * *$ at $5 \%$ and $* * *$ at $1 \%$ level of confidence.

\begin{tabular}{|c|c|c|c|c|c|c|c|c|c|}
\hline \multirow[b]{2}{*}{ Financial sector indicators } & \multicolumn{2}{|l|}{ 1) } & \multicolumn{3}{|c|}{ 2) } & \multicolumn{2}{|r|}{ 3) } & \multirow[b]{3}{*}{$(0.110)$} & \multirow[b]{3}{*}{$* * *$} \\
\hline & & & & & & & & & \\
\hline Foreign banks & 0.533 & $(0.080)$ & $* * *$ & 0.574 & $(0.074)$ & $* * *$ & 0.648 & & \\
\hline State-owned banks 2004 & 0.582 & $(0.137)$ & $* * *$ & 0.558 & $(0.138)$ & $* * *$ & 0.623 & $(0.143)$ & $* * *$ \\
\hline Number of banks 2004 & 0.005 & $(0.001)$ & $* * *$ & 0.005 & $(0.001)$ & $* * *$ & 0.005 & $(0.001)$ & $* * *$ \\
\hline \multicolumn{10}{|l|}{ Firm controls } \\
\hline Small firm dummy & 0.107 & $(0.046)$ & $* *$ & 0.105 & $(0.047)$ & $* *$ & 0.104 & $(0.047)$ & $* *$ \\
\hline Transparent firm dummy & -0.260 & $(0.059)$ & $* * *$ & -0.236 & $(0.059)$ & $* * *$ & -0.268 & $(0.059)$ & $* * *$ \\
\hline Profit margins 2004 & -0.001 & $(0.001)$ & & -0.001 & $(0.001)$ & & -0.001 & $(0.001)$ & \\
\hline Foreign -owned firm (share ownership 2004) & -0.005 & $(0.001)$ & $* * *$ & -0.005 & $(0.001)$ & $* * *$ & -0.005 & $(0.001)$ & $* * *$ \\
\hline Exports (\% over total sales 2004$)$ & 0.000 & $(0.001)$ & & 0.000 & $(0.001)$ & & 0.000 & $(0.001)$ & \\
\hline \multicolumn{10}{|l|}{ Macro controls } \\
\hline Inflation (average 2002-2004) & 1.089 & $(0.375)$ & $* * *$ & 1.316 & $(0.385)$ & $* * *$ & 1.210 & $(0.392)$ & $* * *$ \\
\hline Government debt (2004) & 0.673 & $(0.116)$ & $* * *$ & 0.842 & $(0.114)$ & $* * *$ & 0.630 & $(0.128)$ & $* * *$ \\
\hline Constant & -1.746 & $(0.096)$ & $* * *$ & -1.830 & $(0.098)$ & $* * *$ & -1.812 & $(0.106)$ & $* * *$ \\
\hline Number of obs $=$ & 6189 & & & 6189 & & & 6189 & & \\
\hline Wald chi2 $(10)=$ & 216.95 & & & 227.12 & & & 201.54 & & \\
\hline Prob $>$ chi $2=$ & 0 & & & 0 & & & 0 & & \\
\hline Pseudo R2 = & 0.0384 & & & 0.0407 & & & & & \\
\hline
\end{tabular}

Probability of credit constraints associated with different levels of foreign bank penetration (based on col. 2)

Foreign bank share

$5 \%$
$50 \%$

$75 \%$
Associated probability

$$
\begin{aligned}
& 11 \% \\
& 17 \%
\end{aligned}
$$$$
25 \%
$$ 
Table 5 Impact of foreign banks and concentration on credit constraints of firms by size

\begin{tabular}{|c|c|c|c|c|c|c|}
\hline \multicolumn{7}{|c|}{$\begin{array}{l}\text { Probit regression including the same explanatory variabes as in table } 4 ; * \text { denotes significance at } 10 \% \text {, } \\
* * \text { at } 5 \% \text { and } * * * \text { at } 1 \% \text { levels of confidence. }\end{array}$} \\
\hline & \multicolumn{3}{|c|}{ Cost } & \multicolumn{3}{|c|}{ Access } \\
\hline & Coef. & Std. Err & & Coef. & Std. Err & \\
\hline Foreign banks $2001 *$ small firm & 0.355 & $(0.079)$ & $* * *$ & 0.619 & $(0.084)$ & **** \\
\hline Foreign banks $2001 *$ large firm & 0.187 & $(0.124)$ & & 0.434 & $(0.133)$ & $* * *$ \\
\hline Number of banks * small firm & 0.005 & $(0.001)$ & $* * *$ & 0.004 & $(0.001)$ & $* * *$ \\
\hline Number of banks * large firm & 0.008 & $(0.001)$ & $* * *$ & 0.007 & $(0.001)$ & $* * *$ \\
\hline Small firm & 0.270 & $(0.066)$ & $* * *$ & 0.204 & $(0.070)$ & $* *$ \\
\hline Constant & -1.594 & $(0.088)$ & $* * *$ & -1.633 & $(0.093)$ & $* * *$ \\
\hline Number of obs $=$ & 6189 & & & 6189 & & \\
\hline Wald chi2 $(10)=$ & 309.36 & & & 232.65 & & \\
\hline Prob $>$ chi $2=$ & 0 & & & 0 & & \\
\hline Pseudo R2 = & 0.0475 & & & 0.0419 & & \\
\hline
\end{tabular}

Table 6 Impact of foreign banks and concentration on credit constraints of firms by transparency

Probit regression including the same explanatory variabes as in table $4 ; *$ denotes significance at $10 \%$,

$* *$ at $5 \%$ and $* * *$ at $1 \%$ levels of confidence.

\begin{tabular}{|c|c|c|c|c|c|c|}
\hline & \multicolumn{3}{|c|}{ Cost } & \multicolumn{3}{|c|}{ Access } \\
\hline & Coef. & Std. Err & & Coef. & Std. Err & \\
\hline Foreign banks $2001 *$ transparent firm & -0.360 & $(0.175)$ & ** & -0.151 & $(0.188)$ & \\
\hline Foreign banks $2001 *$ opaque firm & 0.440 & $(0.075)$ & *** & 0.701 & $(0.080)$ & **** \\
\hline Number of banks * transparent firm & 0.006 & $(0.001)$ & *** & 0.005 & $(0.001)$ & **** \\
\hline Number of banks $*$ opaque firm & 0.006 & $(0.001)$ & $* * *$ & 0.005 & $(0.001)$ & *** \\
\hline Transparent firm & -0.151 & $(0.081)$ & * & -0.213 & $(0.088)$ & ** \\
\hline Small firm & 0.134 & $(0.044)$ & $* * *$ & 0.106 & $(0.047)$ & ** \\
\hline Constant & -1.446 & $(0.080)$ & $* * *$ & -1.506 & $(0.085)$ & **** \\
\hline Number of obs $=$ & 6189 & & & 6189 & & \\
\hline Wald chi2(10) $=$ & 327.38 & & & 248.17 & & \\
\hline Prob $>$ chi $2=$ & 0 & & & 0 & & \\
\hline Pseudo R2 = & 0.0485 & & & 0.0441 & & \\
\hline
\end{tabular}




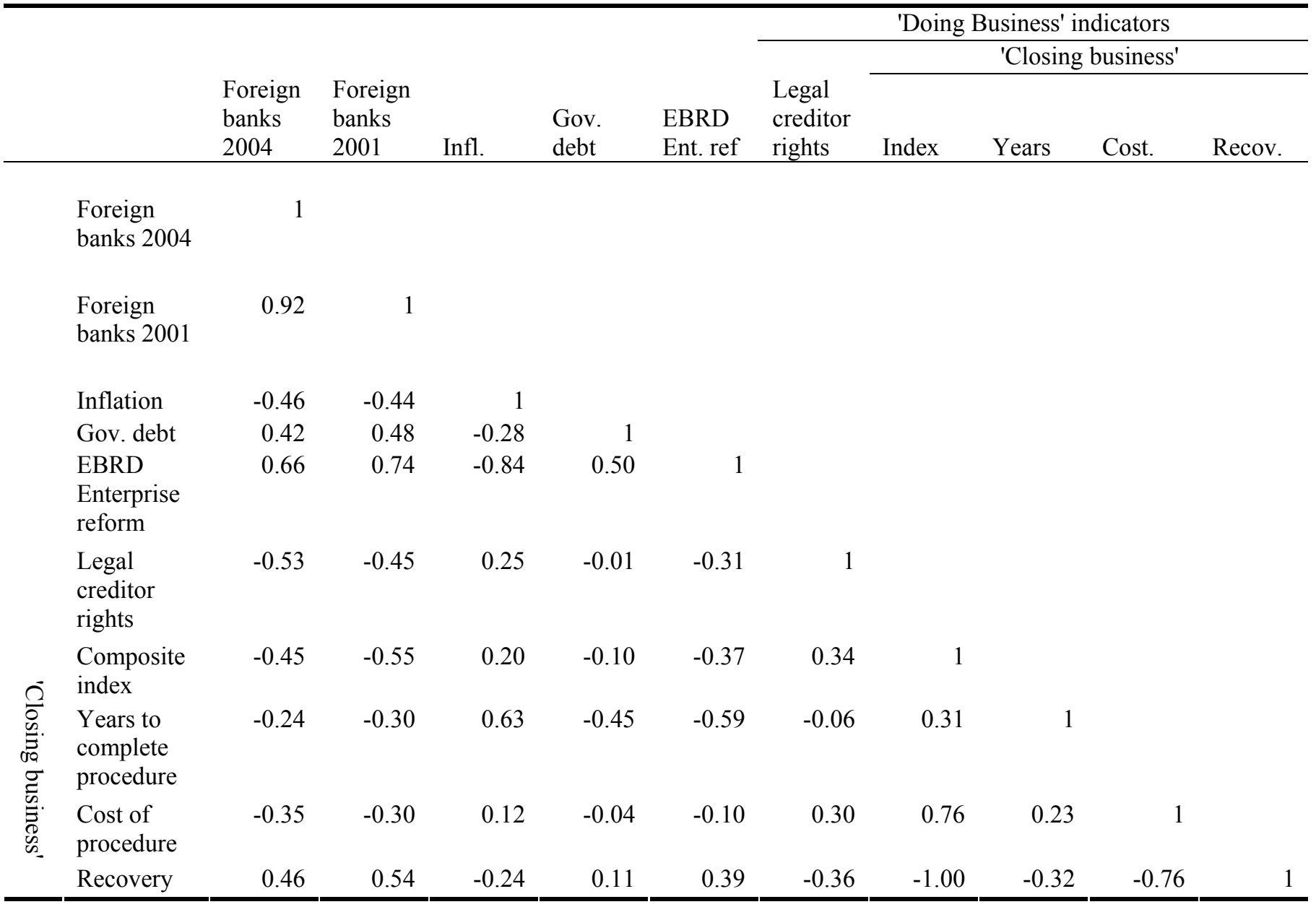


Table 8a) Impact of institutions on credit constraints: Dependent variable is cost of credit. Probit regressions

\begin{tabular}{|c|c|c|c|c|c|c|c|c|c|c|c|c|}
\hline & Coeff. & $\begin{array}{l}\text { Std. } \\
\text { error }\end{array}$ & & Coeff. & $\begin{array}{l}\text { Std. } \\
\text { error }\end{array}$ & & Coeff. & $\begin{array}{l}\text { Std. } \\
\text { error }\end{array}$ & & Coeff. & $\begin{array}{l}\text { Std. } \\
\text { error }\end{array}$ & \\
\hline \multicolumn{13}{|l|}{ Indicator of creditor rights } \\
\hline Log(per capita GDP) & & & & & & & -0.056 & $(0.030)$ & $*$ & -0.013 & $(0.030)$ & \\
\hline Cost of proceedings ( $\%$ of estate $)$ & 0.019 & $(0.006)$ & $* * *$ & & & & 0.022 & $(0.006)$ & $* * *$ & & & \\
\hline Years to complete proceedings & & & & 0.177 & $(0.041)$ & $* * *$ & & & & 0.176 & $(0.041)$ & $* * *$ \\
\hline \multicolumn{13}{|l|}{ Financial sector indicators } \\
\hline Foreign banks 2001 & 0.273 & $(0.088)$ & $* * *$ & 0.299 & $(0.085)$ & $* * *$ & 0.430 & $(0.120)$ & $* * *$ & 0.340 & $(0.124)$ & $* * *$ \\
\hline State-owned banks 2004 & -0.220 & $(0.144)$ & & -0.339 & $(0.149)$ & & -0.204 & $(0.145)$ & & -0.327 & $(0.151)$ & $* *$ \\
\hline Number of banks 2004 & 0.001 & $(0.001)$ & & 0.005 & $(0.001)$ & $* * *$ & 0.000 & $(0.002)$ & & 0.005 & $(0.001)$ & $* * *$ \\
\hline \multicolumn{13}{|l|}{ Firm controls } \\
\hline Small firm dummy & 0.131 & $(0.047)$ & $* * *$ & 0.125 & $(0.047)$ & $* * *$ & 0.131 & $(0.047)$ & $* * *$ & 0.125 & $(0.047)$ & $* * *$ \\
\hline Transparent firm dummy & -0.199 & $(0.061)$ & $* * *$ & -0.238 & $(0.061)$ & $* * *$ & -0.206 & $(0.061)$ & $* * *$ & -0.241 & $(0.061)$ & $* * *$ \\
\hline Profit margins 2004 & -0.001 & $(0.001)$ & & -0.001 & $(0.001)$ & & 0.000 & $(0.001)$ & & -0.001 & $(0.001)$ & \\
\hline Foreign -owned firm (share ownership 2004) & -0.005 & $(0.001)$ & $* * *$ & -0.005 & $(0.001)$ & $* * *$ & -0.005 & $(0.001)$ & $* * *$ & -0.005 & $(0.001)$ & $* * *$ \\
\hline Exports (\% over total sales 2004$)$ & -0.001 & $(0.001)$ & & -0.001 & $(0.001)$ & & -0.001 & $(0.001)$ & & -0.001 & $(0.001)$ & \\
\hline \multicolumn{13}{|l|}{ Macro controls } \\
\hline Inflation (average 2002-2004) & 1.517 & $(0.399)$ & $* * *$ & 0.519 & $(0.484)$ & & 1.366 & $(0.412)$ & $* * *$ & 0.491 & $(0.484)$ & \\
\hline Government debt (2004) & 1.642 & $(0.158)$ & $* * *$ & 1.786 & $(0.166)$ & $* * *$ & 1.543 & $(0.162)$ & $* * *$ & 1.758 & $(0.173)$ & $* * *$ \\
\hline Constant & -1.751 & $(0.095)$ & $* * *$ & -2.128 & $(0.136)$ & $* * *$ & -1.748 & $(0.095)$ & $* * *$ & -2.123 & $(0.136)$ & $* * *$ \\
\hline Number of obs & 5227 & & & 5227 & & & 5227 & & & 5227 & & \\
\hline Wald chi2(11) & 337.91 & & & 336.05 & & & 338.88 & & & 336.05 & & \\
\hline Prob $>$ chi 2 & 0 & & & 0 & & & 0 & & & 0 & & \\
\hline Pseudo R2 & 0.0592 & & & 0.0602 & & & 0.0598 & & & 0.0602 & & \\
\hline
\end{tabular}

Impact of improvements of creditor rights on the predicted probability that the cost of credit is a major obstacle to firm growth, based on columns 7 and 9

Cost of proceedings

Improvement $\quad 42 \quad 13 \quad 4$

Predicted probability $\quad 0.45 \quad 0.22 \quad 0.16$
Years to complete proceedings 
Table 8b) Impact of institutions on credit constraints: Dependent variable is access to credit Probit regressions

\begin{tabular}{|c|c|c|c|c|c|c|c|c|c|c|c|c|}
\hline & Coeff. & $\begin{array}{l}\text { Std. } \\
\text { error }\end{array}$ & & Coeff. & $\begin{array}{l}\text { Std. } \\
\text { error }\end{array}$ & & Coeff. & Std. error & & Coeff. & Std. error & \\
\hline \multicolumn{13}{|l|}{ Indicator of creditor rights } \\
\hline $\log ($ per capita GDP $)$ & & & & & & & 0.042 & $(0.032)$ & & 0.032 & $(0.032)$ & \\
\hline Cost of proceedings ( $\%$ of estate $)$ & 0.006 & $(0.006)$ & & & & & & & & 0.004 & $(0.006)$ & \\
\hline Years to complete proceedings & & & & 0.108 & $(0.045)$ & $* *$ & 0.110 & $(0.045)$ & $* *$ & & & \\
\hline \multicolumn{13}{|l|}{ Financial sector indicators } \\
\hline Foreign banks 2001 & 0.577 & $(0.097)$ & $* * *$ & 0.562 & $(0.094)$ & $* * *$ & 0.431 & $(0.135)$ & $* * *$ & 0.490 & $(0.129)$ & $* * *$ \\
\hline State-owned banks 2004 & 0.423 & $(0.147)$ & $* * *$ & 0.291 & $(0.159)$ & $*$ & 0.255 & $(0.163)$ & & 0.415 & $(0.148)$ & $* * *$ \\
\hline Number of banks 2004 & 0.003 & $(0.002)$ & $* *$ & 0.005 & $(0.001)$ & $* * *$ & 0.004 & $(0.001)$ & $* * *$ & 0.004 & $(0.002)$ & $* *$ \\
\hline \multicolumn{13}{|l|}{ Firm controls } \\
\hline Small firm dummy & 0.108 & $(0.051)$ & $* *$ & 0.108 & $(0.051)$ & $* *$ & 0.109 & $(0.051)$ & $* *$ & 0.109 & $(0.051)$ & $* *$ \\
\hline Transparent firm dummy & -0.271 & $(0.067)$ & $* * *$ & -0.287 & $(0.067)$ & $* * *$ & -0.279 & $(0.067)$ & $* * *$ & -0.267 & $(0.067)$ & $* * *$ \\
\hline Profit margins 2004 & -0.002 & $(0.001)$ & & -0.002 & $(0.001)$ & & -0.002 & $(0.001)$ & & -0.002 & $(0.001)$ & \\
\hline Foreign -owned firm (share ownership 2004) & -0.005 & $(0.001)$ & $* * *$ & -0.005 & $(0.001)$ & $* * *$ & -0.005 & $(0.001)$ & $* * *$ & -0.005 & $(0.001)$ & $* * *$ \\
\hline Exports (\% over total sales 2004$)$ & 0.000 & $(0.001)$ & & 0.000 & $(0.001)$ & & 0.000 & $(0.001)$ & & 0.000 & $(0.001)$ & \\
\hline \multicolumn{13}{|l|}{ Macro controls } \\
\hline Inflation (average 2002-2004) & 1.577 & $(0.413)$ & $* * *$ & 0.924 & $(0.514)$ & $*$ & 0.996 & $(0.513)$ & $*$ & 1.661 & $(0.422)$ & $* * *$ \\
\hline Government debt (2004) & 1.052 & $(0.169)$ & $* * *$ & 1.168 & $(0.180)$ & $* * *$ & 1.248 & $(0.192)$ & $* * *$ & 1.103 & $(0.177)$ & $* * *$ \\
\hline Constant & -1.878 & $(0.101)$ & $* * *$ & -2.123 & $(0.146)$ & $* * *$ & -2.136 & $(0.147)$ & $* * *$ & -1.880 & $(0.101)$ & $* * *$ \\
\hline Number of obs & 5227 & & & 5227 & & & 5227 & & & 5227 & & \\
\hline Wald chi2(11) & 245.07 & & & 249.08 & & & 251.67 & & & 246.86 & & \\
\hline Prob $>$ chi2 & 0 & & & 0 & & & 0 & & & 0 & & \\
\hline Pseudo R2 & 0.0506 & & & 0.0516 & & & 0.0519 & & & 0.0508 & & \\
\hline \multicolumn{13}{|c|}{ Impact of improvements of creditor rights on thepredicted probability that access to credit is a major obstacle to firm growth, based on columns 7 and 9} \\
\hline & \multicolumn{3}{|c|}{ Cost of proceedings } & \multicolumn{4}{|c|}{$\begin{array}{c}\text { Years to complete } \\
\text { proceedings }\end{array}$} & & & & & \\
\hline Improvement & 42 & 15 & 4 & & 5.8 & 2.9 & 1.7 & & & & & \\
\hline Predicted probability & 0.20 & 0.18 & 0.17 & & 0.27 & 0.17 & 0.14 & & & & & \\
\hline
\end{tabular}


Table 9 a) Interaction effect of foreign banks and institutions on credit constraints Dependent variable is cost of credit

Corrected interaction term Foreign banks* Institutions. Stata estimation with 'inteff'. Based on the following probit regressions: $\operatorname{Pr}\left(\right.$ Credit constraint $\left._{i, j}=1\right)=\mathrm{j}(\mathrm{bo}+\mathrm{b}$ linstitution indicator $+\mathrm{b} 2$ Foreign bank share $_{j}+$ b3Institutions indicator*Foreign bank share $\left.{ }_{j}+\mathrm{b} 4 \mathrm{Fij}+\mathrm{b}_{5} \mathrm{C}_{j}\right)$ ) where firm controls (Fij) and country level controls (Cj) are the same as in table 2

\begin{tabular}{llllll}
\hline & Mean & $\begin{array}{l}\text { Std. } \\
\text { Dev. }\end{array}$ & Min & Max & Obs \\
\hline Foreign banks* cost of proceedings & & & & & \\
& & & & & \\
Corrected coefficent & 0.019 & 0.005 & 0.003 & 0.026 & 5227 \\
Standard error & 0.004 & 0.001 & 0.001 & 0.006 & 5227 \\
z statistic & 4.382 & 0.559 & 2.521 & 5.950 & 5227 \\
& & & & & \\
Foreign banks* time to complete proceedings & & & & & \\
Corrected coefficent & 0.091 & 0.022 & 0.014 & 0.117 & 5227 \\
Standard error & 0.041 & 0.012 & 0.005 & 0.057 & 5227 \\
z statistic & 2.284 & 0.256 & 1.976 & 3.459 & 5227 \\
\hline
\end{tabular}

Table 9 b) Interaction effect of foreign banks and institutions on credit constraints Dependent variable is access to credit

Corrected interaction term Foreign banks* Institutions. Stata estimation with 'inteff'. Based on the following probit regressions: $\operatorname{Pr}\left(\right.$ Credit constraint $\left._{i, j}=1\right)=\mathrm{j}(\mathrm{bo}+\mathrm{b}$ 1institution indicator $+\mathrm{b} 2$ Foreign bank share $_{j}+\mathrm{b} 3$ Institutions indicator*Foreign bank share $\left.{ }_{j}+\mathrm{b} 4 \mathrm{Fij}+\mathrm{b} 5 \mathrm{C}_{j}\right)$ ) where firm controls (Fij) and country level controls (Cj) are the same as in table 2

\begin{tabular}{lrrrrr}
\hline & Mean & $\begin{array}{l}\text { Std. } \\
\text { Dev. }\end{array}$ & Min & Max & Obs \\
\hline Foreign banks* cost of proceedings & & & & & \\
& & & & & \\
Corrected coefficent & 0.018 & 0.008 & -0.004 & 0.031 & 5227 \\
Standard error & 0.004 & 0.002 & 0.001 & 0.007 & 5227 \\
z statistic & 4.346 & 1.170 & -0.819 & 7.343 & 5227 \\
& & & & & \\
Foreign banks* time to complete proceedings & & & & & \\
Corrected coefficent & 0.047 & 0.013 & 0.008 & 0.065 & 5227 \\
Standard error & 0.037 & 0.014 & 0.004 & 0.059 & 5227 \\
z statistic & 1.362 & 0.216 & 1.100 & 2.140 & 5227 \\
\hline
\end{tabular}




\section{Swiss National Bank Working Papers published since 2004:}

2004-1 Samuel Reynard: Financial Market Participation and the Apparent Instability of Money Demand

2004-2 Urs W. Birchler and Diana Hancock: What Does the Yield on Subordinated Bank Debt Measure?

2005-1 Hasan Bakhshi, Hashmat Khan and Barbara Rudolf: The Phillips curve under state-dependent pricing

2005-2 Andreas M. Fischer: On the Inadequacy of Newswire Reports for Empirical Research on Foreign Exchange Interventions

2006-1 Andreas M. Fischer: Measuring Income Elasticity for Swiss Money Demand: What do the Cantons say about Financial Innovation?

2006-2 Charlotte Christiansen and Angelo Ranaldo: Realized Bond-Stock Correlation: Macroeconomic Announcement Effects

2006-3 Martin Brown and Christian Zehnder: Credit Reporting, Relationship Banking, and Loan Repayment

2006-4 Hansjörg Lehmann and Michael Manz: The Exposure of Swiss Banks to Macroeconomic Shocks - an Empirical Investigation

2006-5 Katrin Assenmacher-Wesche and Stefan Gerlach: Money Growth, Output Gaps and Inflation at Low and High Frequency: Spectral Estimates for Switzerland

2006-6 Marlene Amstad and Andreas M. Fischer: Time-Varying Pass-Through from Import Prices to Consumer Prices: Evidence from an Event Study with Real-Time Data

2006-7 Samuel Reynard: Money and the Great Disinflation

2006-8 Urs W. Birchler and Matteo Facchinetti: Can bank supervisors rely on market data? A critical assessment from a Swiss perspective

2006-9 Petra Gerlach-Kristen: A Two-Pillar Phillips Curve for Switzerland

2006-10 Kevin J. Fox and Mathias Zurlinden: On Understanding Sources of Growth and Output Gaps for Switzerland

2006-11 Angelo Ranaldo: Intraday Market Dynamics Around Public Information Arrivals

2007-1 Andreas M. Fischer, Gulzina Isakova and Ulan Termechikov: Do FX traders in Bishkek have similar perceptions to their London colleagues? Survey evidence of market practitioners' views 
2007-2 Ibrahim Chowdhury and Andreas Schabert: Federal Reserve Policy viewed through a Money Supply Lens

2007-3 Angelo Ranaldo: Segmentation and Time-of-Day Patterns in Foreign Exchange Markets

2007-4 Jürg M. Blum: Why `Basel II’ May Need a Leverage Ratio Restriction

2007-5 Samuel Reynard: Maintaining Low Inflation: Money, Interest Rates, and Policy Stance

2007-6 Rina Rosenblatt-Wisch: Loss Aversion in Aggregate Macroeconomic Time Series

2007-7 Martin Brown, Maria Rueda Maurer, Tamara Pak and Nurlanbek Tynaev: Banking Sector Reform and Interest Rates in Transition Economies: Bank-Level Evidence from Kyrgyzstan

2007-8 Hans-Jürg Büttler: An Orthogonal Polynomial Approach to Estimate the Term Structure of Interest Rates

2007-9 Raphael Auer: The Colonial Origins Of Comparative Development: Comment. A Solution to the Settler Mortality Debate

2007-10 Franziska Bignasca and Enzo Rossi: Applying the Hirose-Kamada filter to Swiss data: Output gap and exchange rate pass-through estimates

2007-11 Angelo Ranaldo and Enzo Rossi: The reaction of asset markets to Swiss National Bank communication

2007-12 Lukas Burkhard and Andreas M. Fischer: Communicating Policy Options at the Zero Bound

2007-13 Katrin Assenmacher-Wesche, Stefan Gerlach, and Toshitaka Sekine: Monetary Factors and Inflation in Japan

2007-14 Jean-Marc Natal and Nicolas Stoffels: Globalization, markups and the natural rate of interest

2007-15 Martin Brown, Tullio Jappelli and Marco Pagano: Information Sharing and Credit: Firm-Level Evidence from Transition Countries

2007-16 Andreas M. Fischer, Matthias Lutz and Manuel Wälti: Who Prices Locally? Survey Evidence of Swiss Exporters

2007-17 Angelo Ranaldo and Paul Söderlind: Safe Haven Currencies 
2008-1 Martin Brown and Christian Zehnder: The Emergence of Information Sharing in Credit Markets

2008-2 Yvan Lengwiler and Carlos Lenz: Intelligible Factors for the Yield Curve

2008-3 Katrin Assenmacher-Wesche and M. Hashem Pesaran: Forecasting the Swiss Economy Using VECX* Models: An Exercise in Forecast Combination Across Models and Observation Windows

2008-4 Maria Clara Rueda Maurer: Foreign bank entry, institutional development and credit access: firm-level evidence from 22 transition countries 
Swiss National Bank Working Papers are also available at www.snb.ch, section Publications/Research Subscriptions or individual issues can be ordered at Swiss National Bank, Fraumünsterstrasse 8, CH-8022 Zurich, fax+41 4463181 14, E-mail library@snb.ch 